\title{
The moderating role of corporate reputation and employee-company identification on work-related outcomes of job insecurity resulting from workforce localization policies
}

Article

Accepted Version

Creative Commons: Attribution-Noncommercial-No Derivative Works 4.0

Ali, I., Ali, M., Grigore, G., Molesworth, M. and Jin, Z. (2020) The moderating role of corporate reputation and employeecompany identification on work-related outcomes of job insecurity resulting from workforce localization policies. Journal of Business Research, 117. pp. 825-838. ISSN 01482963 doi: https://doi.org/10.1016/j.jbusres.2019.02.060 Available at https://centaur.reading.ac.uk/82037/

It is advisable to refer to the publisher's version if you intend to cite from the work. See Guidance on citing.

To link to this article DOI: http://dx.doi.org/10.1016/j.jbusres.2019.02.060

Publisher: Elsevier

All outputs in CentAUR are protected by Intellectual Property Rights law, including copyright law. Copyright and IPR is retained by the creators or other copyright holders. Terms and conditions for use of this material are defined in the End User Agreement. 


\section{www.reading.ac.uk/centaur}

\section{CentAUR}

Central Archive at the University of Reading

Reading's research outputs online 


\title{
The moderating role of corporate reputation and employee-company identification on the work-related outcomes of job insecurity resulting from workforce localization policies
}

\begin{abstract}
:
Although previous studies have examined the impact of job insecurity, there remains a need to understand specific issues related to job insecurity that results from government workforce localization policies. This study addresses this gap by examining employees' work-related outcomes: employee engagement, job burnout, and intentions to quit, recognizing the interplay of employees' identification with an organization and perceived corporate reputation in the context of Saudi Arabia's localization policies. The study uses social identification theory to explain how employees' perception of corporate reputation and their identification with a company shape their work attitudes in the presence of job-insecurity. Partial least square - path modeling (PLS-PM) and PROCESS tool is used to test hypotheses from data collected from 135 expatriate migrant employees working in different organizations in Saudi Arabia. Findings show that job insecurity has a significant effect of reducing the engagement of immigrant employees and leads to increased employee burnout and intentions to quit jobs. The results of moderation analysis show that favorable corporate reputation reduces the negative impact of job insecurity on employee's burnout and intentions to quit, whereas high level of identification with company may also reduce employee burnout, even during job insecurity. Although immigrant employees do not seek to leave a reputable organization due to localization policies, they still experience stress, become disengaged, and so are less productive. As a result, businesses should leverage their reputation towards governmental policies of localization, by advocating expatriate employees' contributions towards organizations and economy.
\end{abstract}


Keywords: Job insecurity, employee engagement, job burnout, corporate reputation, employeecompany identification, workforce localization.

\section{Introduction}

In recent years, and especially following the economic downturn in 2008 , there have been renewed government policies directed at reducing immigration and localizing job markets (Ruhs and Anderson, 2010). This is noted in diverse locations, for example in the US, with the Trump administration developing policy to reduce immigrant labor (Alexander, 2017; Payan, 2016), in the EU and particularly the UK, with the conservative government promising reduced immigration, with implied positive impact on employment for UK workers (BBC, 2017; O'Rourke, 2016), in Singapore, with policy tensions over the need for immigration and local anti-immigrant sentiment (Tan, 2017), and particularly, in Arab countries including; Saudi Arabia, Bahrain, Kuwait, Omanm, United Arab Emirates, and Qatar, all of which have pre-existing and ongoing workforce localization policies to deal with unemployment issues in the local population (Hasan, 2014; Al-Asfour and Khan, 2014).

There are, however, significant implications for businesses that rely on an immigrant labor force in such a policy environment. This is specifically the case in Saudi Arabia - our context that has established quotas for 'Saudization', the employment of local workers, (Ramady, 2013; Al-Asfour and Khan, 2014). Saudization has resulted in dubious practices such as 'Ghost Workers', local employees who are paid, but not required to work (Al-Asfour and Khan, 2014) as organizations attempt to deal with the policy, whilst managing their labor needs, and avoiding extra payments to the government. Nevertheless, the result is that expatriate workers are experiencing job insecurity, with related negative effects on their wellbeing, work behaviors and 
intention to quit, which in turn risks productivity and so also economic growth (Cheng and Chan, 2008; Niesen et al., 2018; Piccoli and De Witte, 2015; Piccoli et al. 2017; and Sverke, Hellgren and Näswall, 2002). Businesses that are subject to localization policies remain reliant on immigrant labor that is able to undertake work without the negative effects that come with job insecurity (and indeed may prefer these workers, see Ramady, 2005; 2013) and it is important that they therefore understand how best to manage immigrant employees who are effected by such policy Indeed, both businesses and governments can benefit from an understanding of how to maintain immigrant employee productivity during any transition to localization.

One defense against the negative consequences of government policy directed towards workforce localization should be the reputation of the organization itself, and related employee organizational identification. Specifically, corporate reputation is recognized as an important asset that can protect corporations (Ali et al., 2015; Foroudi et al., 2016; Tischer \& Hildebrandt, 2014; Wang et al., 2016; Tucker \& Melewar, 2005), with positive corporate reputation shaping favorable stakeholder behaviors (Ali et al., 2015; Gaultier-Gaillard \& Louisot, 2006; Tischer \& Hildebrandt, 2014) and with resulting positive employee organizational identification (Ashforth \& Mael, 1989; DeConinck, 2011). Put simply, those organizations with a better reputation, and stronger employee identification may be better placed to avoid negative employee behaviors associated with policyinduced job insecurity.

This study examines the association between job insecurity and the potential work-related outcomes of localization, captured by employee engagement, burnout, and intention to quit, with corporate reputation and employee identification as moderating variables. The context is Saudi Arabia, a country with one of the most developed and sustained policies of workforce localization (Hasan, 2014; Al-Asfour and Khan, 2014). The contributions of the paper are manifold: (i) it 
examines the work-related outcomes of job insecurity in the environment of localization of job market policies, (ii) it offers an understanding of the moderating roles of corporate reputation and employee-company identification amid job insecurity, and its effect on work-related outcomes, and (iii); it offers practical implications to allow corporate managers to increase positive employee outcomes and to avoid negative employee outcomes amid conditions of job insecurity.

\section{Theoretical background and hypotheses}

Localization policies have work-related implications (Hasan, 2014). Indeed, increased job insecurity for immigrant employees is a specific intention of the policy, with possibilities of either immigrant employee disengagement, an increased intention to quit, or at best a desire to work harder to maintain their vulnerable position regardless of the impact on their wellbeing. We might therefore also consider the risk of burnout under these increasing work-related pressures (Bosman et al., 2005; and Manzano-García and Ayala, 2017). Taken together then, engagement, burnout, and intention to quit represent work-related outcomes of localization policies that may be measured in this study.

Amid such a situation it is challenging for organizations to keep their employees motivated, yet organizations with a strong reputation may find this easier to achieve. This research therefore further proposes that corporate reputation and related employee-company identification may yield positive work behavior, even amid policy-induced job insecurity, noting that where both are high, negative outcomes (burnout and intention to quit) should be less evident, and positive outcomes (engagement) should be more present.

Although several studies have examined the impact of job insecurity on employees' work related outcomes (for instance Bosman, 2005, Gosh, 2017; Niesen, et al., 2018; and Piccoli et al., 
2017), the key constructs that reduce negative employee outcomes, and/or increase positive employee related outcomes amid policy-induced job insecurity have not been identified. The current study therefore offers an important contribution by examining the impact of job insecurity caused by localization policies on expatriate (immigrant) workers. Specifically, it examines how both corporate reputation and social identity related to an organization (Tajfel and Turner, 1979) moderate the relationship between job insecurity - as a psychological contract breach - and expatriate employees' work-related outcomes. In doing so important implications for business managers are identified. To ensure productivity managers need to understanding and address factors that impact on employee engagement, help them to aviod burnout, and reduce their intentions to leave, even when there are government policies that increase job insecurity.

\subsection{Job insecurity and work-related outcomes}

Since 1970s there has been substantial research on job insecurity and its influence on employee behaviors (Ashford et al., 1989; Cobb \& Kasl, 1977). Job insecurity refers to a "sense of powerlessness to maintain desired continuity in a threatened job situation" (Greenhalgh and Rosenblatt (1984, p. 438). Individuals experience job insecurity as threatening, and it is one of the most important work-related stressors (De Witte, 1999). Even though it may sometimes result in stress induced pro-organizational performance by employees, this is also detrimental for organizations in long-term (Gosh, 2017) as job insecurity can result in a deterioration of somatic or mental health (Ashford et al., 1989; Cobb \& Kasl, 1977; Hartley et al., 1991). It is also related to negative behaviors such as disengagement, increased burnout, and intention to quit (Ashford et al., 1989; Cuyper et al., 2008; Hallier \& Lyon, 1996; Meyer \& Parfyonova, 2010), as well as a decline in job satisfaction, organizational commitment and employee attachment (Furaker \& Berglund, 2014; Hallier \& Lyon, 1996; Hartley et al., 1991). Overall, job insecurity can also 
produce a decline in employee innovation (Neison, 2018), and lower employee performance (Piccoli, 2017). The result of all of this is that it can lead to increased costs for organizations, for example through absence and lowered productivity (Laszlo et al., 2010).

\subsection{Job insecurity and employee engagement}

Improving employee engagement activities has become popular among consulting firms. Schaufeli \& Bakker, (2003) define employee engagement as: "a positive, fulfilling, work-related state of mind that is characterized by three interrelated dimensions, namely vigor, dedication, and absorption". Employee engagement is about being psychologically present when performing a role, and represents both emotional and intellectual commitment, and a discretionary effort towards an organization (Richman, 2006). Numerous studies have also examined the influence of job insecurity on employee engagement, for instance, Cheng et al., (2005); De Witte, (1999); and Presti and Nonnis (2012) noted negative effects of job insecurity on employee engagement. Similarly, Greasley et al. (2005); and Stander and Rothmann (2010) hold that employees who perceive high levels of job insecurity work with less vigor and dedication, and hence display lower levels of engagement with their organization. We might therefore assume that expatriate employees who perceive high job insecurity as a result of by localization policy will lose interest and dedication towards the organization they work for. This paper therefore, hypothesizes that job insecurity negatively affects employee engagement.

H1: Job insecurity is negatively related to employee engagement.

\subsection{Job insecurity and burnout}

Burnout is defined as a syndrome related to feeling emotionally overwhelmed by work resulting in exhaustion, depersonalization (an impassive and impersonal response towards others) and 
reduced personal accomplishment (a feeling of having less competence and achievement in one's work). Burnout is a response to emotional or interpersonal stressors at work (Maslach \& Jackson, 1981, 1996; Mustafa et al., 2007), and leads to less engagement with one's job (Maslach et al., 2001). There is already evidence in the literature that job insecurity impacts employee burnout. For example, Tilakdharee et al. (2010) found a positive association between job insecurity and an employee burnout inventory. Similarly, Aybas et al., (2015), Chirumbolo and Areni (2005), De Witte, (2005), and McLean, (2006) hold that employees who perceive high level of job insecurity also experience high burnout. Immigrants may already experience considerable stress and mental exhaustion in their jobs as they often work longer hours and have to accomplish challenging tasks

in country where they are also attempting to establish roots. Localization policies can be a significant additional stressor as it impacts on their future work prospects. Hence, the second hypothesis is related to job insecurity and employees' perceptions of burnout.

H2: Job insecurity is positively related to employee burnout.

\subsection{Job insecurity and intentions to quit}

Intention to quit is an individual subjective evaluation with regards to whether one will leave the organization in the near future and is the most immediate predictor of such behavior (Ismail, 2015). In this paper, we use intentions to quit as operationalized by Colarelli (1984), where employees have intentions to search for new job opportunities soon. Previous studies have acknowledged that job insecurity increases intentions to quit, for instance; Bernston et al., (2010); Dekker \& Schaufelli, (1995); Ismail, (2015) argue that job insecurity leads to negative evaluations of organizations by employees and consequently they start searching for other appropriate work. In a recent study, Jimenez et al. (2017) found that job insecurity caused by economic crises (where an organization has to reduce the workforce), led to high stress among employees and intentions 
to quit to find other suitable work. However, little is known about how job insecurity resulting from workforce localizations policies affects intentions to quit. This study therefore proposes that in the context of workforce localization:

H3: Job insecurity is positively related to employees' intentions to quit.

\subsection{The moderating role of corporate reputation}

We might recognize that some organizations may be better placed than others to mitigate negative work related outcomes caused by job insecurity resulting from localization policies. It has already been acknowledged that corporate reputation provides a sustainable competitive advantage to organizations (Ali, 2011; Capozzi, 2005, Zyglidopoulos, 2005) based on the knowledge, beliefs and impression of the organization held by various stakeholders (Ali \& Zia, 2011; Helm \& Tolsdrof, 2013; Musteen et al., 2010; Rhee \& Haunschild, 2006; Su et al., 2016). Fombrun (1996) defines corporate reputation as "set of collectively held beliefs about a company's ability and willingness to satisfy various stakeholders". Once established, a favorable reputation also safeguards an organisation, even in a crisis (Coombs \& Holladay, 2001). Indeed, such is the perceived value of corporate reputation that it has become a key focus for corporate activity as it protects against a wide variety of external circumstances (Coombs \& Holladay, 2001; Highhouse et al., 2009; Zyglidopoulos, 2005). The current study uses employees' assessment of corporate reputation and considers the work behaviors that results from such assessment. Based on socialidentity theory, employees experience a sense of belonging by defining themselves as someone who works for an organization of high repute (Ashforth \& Mael, 1989). Individuals use selective perceptions to assess information to avoid or reduce dissonance (Festinger, 1953; Jain \& Maheswaran, 2000), so that employees with positive attitudes towards a company may disregard later negative information (Helm \& Tolsdrof 2013). Research has also previously examined the 
influence of corporate reputation in increasing employees positive work behaviors such as job satisfaction, commitment, and work engagement, (Helm, 2011, and Shirin \& Kleyn, 2017). Similarly, corporate reputation has been found to reduce employee feelings of burnout and intention to quit (Alniacik et al., 2011, Beheshtifar and Allahyary, 2013). However, in an important report (Deloitte, 2016) proposed that corporate reputation is especially important for corporations in times of crises. Similarly, Coombs \& Holladay (2001), Dean, (2004), Jain \& Maheswaran, (2000), and Watson (2007) also find that corporate reputation is important for organizational survival in times of crises, and in our case this means the negative effects of job insecurity caused by external government policy. As an emerging field, scholars have used different corporate reputation constructs to explain its importance for various stakeholders (Pires,\& Trez, 2018), yet although a number of studies are available that examine the moderating role of corporate reputation in the context of customer behavior (Qasim et al., 2017; and Sridhar and Mehta, 2018) and other stakeholders (Ali et al., 2015), there is little literature available that specifically examines the moderating role of corporate reputation on the relationship between job insecurity and employees work-related outcomes.

Despite the indirect associations available in the literature, there remains insufficient theoretical evidence for the moderating role of corporate reputation on the relationship between job insecurity and employee outcomes. Following these arguments, we therefore propose that favorable corporate reputation reduces the negative effects of job insecurity, whereas unfavorable corporate reputation adversely influences employee engagement.. 
H4a: The negative effect of job insecurity on employee engagement is moderated by perceived corporate reputation. The effect is stronger when corporate reputation is favorable and weaker when corporate reputation is unfavorable.

H4b: The positive effect of job insecurity on employee burnout is moderated by perceived corporate reputation. The effect is stronger when corporate reputation is favorable and weaker when corporate reputation is unfavorable.

H4c: The positive effect of job insecurity on employee intentions to quit is moderated by perceived corporate reputation. The effect is stronger when corporate reputation is favorable and weaker when corporate reputation is unfavorable.

\subsection{The moderating role of employee-company identification}

According to social-identity theory, individuals also attach emotional significance to the groups to which they belong (Tajfel, 1978), with the likelihood of favorable behaviors (Ashforth et al., 2008). These groups include the workplace and so employee-company identification has been defined as: "that part of an individual self-concept which derives from his/her knowledge of his membership of a social group (or groups) together with the value and emotional significance attached to that membership" (Tajfel, 1978, p.63). Employee-company identification postulates that employees value their membership of an organization when they see a good fit between their individual values and organizational values. The concept has been used to explain its effects in developing pride in organizational membership and other employee-related behaviors. Identification with organization is therefore important to employees as they feel that they personally embody organizational values and beliefs (Ashforth \& Mael, 1989; van Knippenberg \& Sleebos, 2006), experiencing high levels of meaning and goal congruence between themselves and the organization (Corley et al., 2006). There is already some limited research that examines 
the positive influence of employees-company identification in increasing positive work behaviors (job satisfaction, commitment, organizational citizenship, work engagement) (Meyer, et al., 2004; Riketta, 2005; and Zafar \& Ali, 2016). Other studies have examined the mediating role of employee company identification in developing positive employee work outcomes (Abdullah, 2017; El-Kassar et al. 2017; and Wang et al., 2017). Guarana, (2010) in particular examined the moderating role of employee organizational identification in increasing employee engagement and reducing burnout. Since an intention to quit a job is also a negative work behavior, it may be assumed that higher levels of employee-company identification will also reduce employees' intentions to quit amid job insecurity. Thus, employees who identify with an organization may experience fewer negative effects from job insecurity, and so also less burnout and a lower intention to quit. In addition, increased job insecurity may not decrease employee engagement if they perceive high level of identification with their organization. Based on these arguments, we propose the following hypotheses.

H5a: The negative effect of job insecurity on employee engagement is moderated by perceived employee-company identification. The effect is stronger when employeecompany identification is favorable and weaker when employee-company identification is unfavorable.

H5b: The negative effect of job insecurity on employee burnout is moderated by perceived employee-company identification. The effect is stronger when employee-company identification is favorable and weaker when employee-company identification is unfavorable. 
H5c: The negative effect of job insecurity on employee intentions to quit is moderated by perceived employee-company identification. The effect is stronger when employeecompany identification is favorable and weaker when employee-company identification is unfavorable.

\subsection{The research model}

We bring these hypotheses together in a conceptual model, Figure 1, that also incorporates control variables including; designation, education and experience that may explain employees' behaviors (employee engagement, employee burnout and intentions to quit). Job insecurity is the independent variable with employee engagement, burnout, and intentions to quit as dependent variables and corporate reputation, and employee company identification as moderating variables. The model explains how corporate reputation and employee company identification affects the work behavior of expatriate employees (the sample) amid job insecurity resulting from localization of the job market in Saudi Arabia. Although there is existing research that examines the association between job insecurity and employee work related outcomes, the conceptual model in this study proposes that organizations can leverage a favorable reputation (as perceived by employees), and employees' identification with the organization, to reduce negative work related outcomes amid insecure job market conditions resulting from external factors, in this case government localization policies. The study offers an incremental contribution to the body of knowledge on this topic by explaining the moderating roles of corporate reputation and employee identification, in the context of the localization of the Saudi labor market. 
Insert Figure 1 here

\section{Method}

\subsection{Context}

The context under investigation is Saudi Arabia, a country that is experiencing ongoing economic issues due to a decline in oil prices following the financial crisis of 2008 , and that is representative of countries where the government has adopted localization policies that have impacted on the workforce. Despite the crisis, Saudi Arabia is a young, rich nation, facing a paradox of high wealth, but also high unemployment among local citizens (Torofdar, 2011), with the job market heavily dependent upon foreign workers (Al-Dosary \& Rahman, 2009). In order to provide employment to local citizens, the government has therefore implemented 'Guided Localization' with the aim of replacing expatriate employees with local Saudis (Saudi Gazetta, 2016, 2017). This has caused unrest among expatriate employees who remain important for the Saudi economy (Aljead, 2014), and indeed businesses have also found the adjustment difficult. Although our focus is Saudi Arabia, this context is transferable to a wider range of countries that are similarly addressing ongoing economic and employment issues through localization policies, for example, the US, UK and Singapore. Like Saudi Arabia, these are also multi-cultural countries dealing with the tensions of globalization following the financial crisis of 2008 .

What limited research exists on the effects of Saudization on the job market in Saudi Arabia focuses on employment opportunities for Saudi citizens, and on the impact on economic growth (Torofdar, 2011), rather than the effects of localization on workplace outcomes for immigrant employees and the organizations they work for. The current research addresses this gap. With the insecurity and associated disillusionment in immigrant employees, there is a greater need for businesses to retain appropriate and necessary overseas workers and maintain, or increase their 
productivity, with the possibility that those businesses with a good reputation, and identification with these employees, are better placed to adjust to localization.

\subsection{Sample and data}

The unit of analysis in this study is the immigrant employees working in Saudi Arabia. Data was collected through personally administered and online survey questionnaires including 135 valid and complete answers from immigrant employees in different organizations in Saudi Arabia (see appendix including demographic profile, education, and designation in the organization, monthly income, and tenure). Participation in the data collection process was voluntary and the confidentiality of the data was assured to respondents. The selection of participants was based on the professional connections of the research team.

Using convenience sampling, 500 expatriates were approached, and invited to participate in the survey, which spanned one month (April 10, 2017 to May 10, 2017). Most respondents who participated were from Egypt (17.8\%), India (12.6\%), Jordan (10.4\%), Sudan (9.6\%), and Yemen $(8.1 \%)$. The sample as a whole reflects the diversity and proportion of different overseas workers in Saudi Arabia. The sample included 67\% males and 33\% females. About 59\% participants had a bachelor's degree and $45 \%$ had masters degrees. Twenty three percent of respondents had 2-5 years of experience, $57 \%$ had 6-10 years, and 12\% had 11-15 years. The smaller female representation also reflects the more limited opportunities for female workers in Saudi Arabia. Appendix 1 shows the demographic characteristics of the sample. 


\subsection{Instruments and measures}

This survey questionnaire was administered in English as a language known to all participants. Previous studies have effectively utilized English surveys in non-native English-speaking countries (Ali et al., 2017; Bouckenooghe et al., 2017' Khan et al., 2015; Naseer et al., 2016). The use of English also provides an opportunity for the comparison of findings with those of previous research that employed English surveys (i.e., primarily conducted in another context; Naseer et al., 2016).

From the review of the literature, various measures have been employed for the constructs including; job insecurity, corporate reputation, employee company identification, and employee engagement, burnout, and intentions to quit. The job insecurity instrument is taken form De Witte (2000) containing 4 items and used by Vander Elst et al. (2014) (i.e., "chances are I will soon lose my job"). All measures are answered on a 5-point Likert ranging from 1 (strongly disagree) to 5 (strongly disagree).

Corporate reputation is measured through an 8-items scale from Feldman \& VasquezParraga (2013) (i.e., "this company contributes actively and voluntarily to the social improvement, economic and the environmental of society" or "this company stands behind its products and services with good price and good quality that meet consumer"). A 6-items scale from Mael \& Ashforth (1992) measures organizational identification (i.e., "when someone criticizes this organization, it feels like a personal insult").

Employee engagement is measured through a scale developed by Saks (2006), with 6 items each for job engagement and organizational engagement (i.e., "I really throw myself into my job", or "being a member of this organization is very captivating"). Job burnout is measured using Maslach \& Jackson's (1981) scale followed by Choi et al. (2012). The study uses two dimensions 
of job burnout: emotional exhaustion (i.e., "I feel emotionally drained from customer service work"), and depersonalization (i.e., "I worry about being callous toward people"), with 4 items each. The final employee behavior - intention to quit - is measured through 3 items scale by Colarelli’s (1984), (i.e., "I frequently think of quitting my job").

Although previous studies have analyzed the influence of the demographics complexity of employees - for instance education, designation, and experience - in different ways (Ageeva et al., 2018; Foroudi et al., 2016), they have not been able to explain their effects on employees work behavior. Hence, in addition to the key hypothesis-testing variables, this study included controls for education, designation, and experience to eliminate whatever effects they might have on employees work behavior. These three variables are measured with nominal scales described in Appendix I.

\subsection{Common method variance}

The data collected for this study is self-reported and cross-sectional as the data for both independent and dependent variables were collected from the same source and at same time. This might mean that the common method variance (CMV) may inflate the strength of observed structural relationships among the constructs in the model. To address the issue of CMV, this study employs Lindell and Whitney's (2001) marker variable analysis. This involves introducing an additional latent variable referred as a "marker variable" that is theoretical unrelated to the main constructs of the study. This study uses "corporate hypocrisy" as a marker variable that is measured by six items adopted from Wagner, Lutz, and Weitz (2009). The data for the marker variable was collected at the same time and in the same manner as the focal variables, and analysis also confirms the reliability and validity of the marker variable (Cronbach's alpha $=0.76$, composite reliability 
$=0.84, \operatorname{AVE}=0.65)$. Table 2 shows that none of the correlations of the marker variable is significant with any other variable, suggesting that the data did not suffer from CMV in this study.

\section{Analysis and results}

\subsection{Statistical method}

This study employed a partial least squares path modeling (PLS-PM) technique (Henseler, Ringle, \& Sarstedt, 2015; Sarstedt, Ringle, \& Hair, 2017; Richter, Cepeda, Roldán, \& Ringle, 2015). Despite a surprising level of enmity towards PLS-PM (Rönkkö \& Evermann, 2013; Rönkkö, McIntosh, \& Antonakis, 2015; Rönkkö, McIntosh, Antonakis, \& Edwards, 2016), PLS-PM has become popular among scholars for its ability to construct theory ((Henseler et al., 2014b; Petter, 2018; Rigdon, 2016; Roldán \& Sánchez-Franco, 2012; Sarstedt, Hair, Ringle, Thiele, \& Gudergan, 2016). The use of PLS-PM in this study was appropriate because: (1) PLS-PM is a suitable approach for prediction oriented research (e.g., predictions of employee behavior); (2) PLS-PM is an appropriate procedure for estimating and testing complex structural relationships; (3) PLS-PM is a convenient tool for handling hierarchical latent variable models (e.g., employee engagement and job burnout); (4) PLS-PM provides latent variables scores which could be used in the subsequent analysis of a two-stage approach for modeling the multidimensionality and moderating analysis; (5) although the sample size $(n=135)$ may seem small, according to statistical power analysis using the $\mathrm{G}^{*}$ Power 3.1.9.2 program (Faul et al., 2007), the model used only required a sample of 45 to detect $R^{2}$ values of around 0.25 , therefore, the statistical power of the sample of 135 samples was acceptable, assuming a significance level of 5\%, a statistical power of $80 \%, 6$ constructs in this study, 37 items, and an effect size of 0.15 (Hair et al., 2017, pp.26), and finally;

(6) the PLS-PM technique provides some of the latest statistical tools such as heterotrait-monotrait (HTMT) ratio for discriminant validity, effect size for relative contribution of each predictor, 
confidence intervals in testing hypothesis, and graphs for moderation analysis. This study used SmartPLS 3 software (Ringle, Wende, Becker, 2015) for the PLS-PM analysis, and a freely available computational tool for SPSS called PROCESS macro (Hayes, 2013) for the conditional moderating analysis.

\subsection{Measurement model assessment}

To assess the measurement model of all reflective first-order constructs, this study focused on the psychometric properties of reliability, validity and dimensionality of each construct as discussed in the following sub-sections. All results of reflective first-order constructs are reported in Step 1 in Table 1.

\subsubsection{Reliability}

The individual reliability of the items was assessed by examining the standardized factor loadings. As a popular rule of thumb Fornell and Larcker (1981) recommend factor loading of $\geq 0.707$, while factor loading $\geq 0.50$ could be considered practically significant for exploratory research (Nunnally, 1978). This study follows Roldán and Sánchez-Franco (2012) recommendation to use two-tailed $p$-values for confirming the significance of factor loadings. The standardized factor loadings of all first order constructs are shown in Step I in Table 1. All factor loadings are found to be above the minimum threshold (i.e., $\geq 0.50$ ), and are significant at $p<0.001$ level (two tailed), indicating convergent validity at the item level. Factor loadings $<0.50$ were dropped during path analysis. The construct reliability was assessed by examining the Cronbach's alpha and composite reliability and should be $\geq 0.70$ (Nunnally, 1978). Step I in Table 1 shows the scores of Cronbach's alpha and composite reliability are $>0.70$, indicating construct reliability. 
Insert Table 1 here

\subsubsection{Convergent validity}

The convergent validity was evaluated be examining the average variance extracted (AVE) and should be $\geq 0.50$ (Fornell and Larcker, 1981). This suggests that $\geq 50$ percent of the item variance should be accounted for. Step I in Table 1 shows that all the constructs have an adequate convergent validity as the values of AVE are $>0.50$.

\subsubsection{Discriminant validity}

This study assesses the discriminant validity using Fornell-Larcker's criterion and the heterotraitmonotrait ratio of correlations (HTMT). Following Fornell-Larcker's (1981) criterion for each pair of constructs, the AVE square root of each construct should be higher than the absolute value of their correlation. Table 2 shows both the AVE square root on the diagonal line for the constructs and the absolute value of their correlation. Secondly, discriminant validity was tested using HTMT. The acceptable values for HTMT should be $<0.85$ HTMT <0.90. The values above the diagonal in Table 2 shows the HTMT values which are $<0.85$, suggesting that discriminant validity was present in this study.

Insert Table 2 here

\subsubsection{Modeling second-order constructs}

Employee engagement and job burnout were operationalized as second-order constructs. Employee engagement was operationalized as a second-order construct, made up of two first-order dimensions: job engagement and organization engagement. As in Table 1 and Fig 1, the two firstorder dimensions reflect the higher-order construct. Similarly, this study measured job burnout as 
a second-order construct consisting of two first-order dimensions: depersonalization and emotional exhaustion. A two-stage approach was employed to evaluate the second-order constructs. In first stage, the reflective items were used to obtain the latent variable scores for all the first-order reflective constructs, which, in the second stage, served as manifest variables in the measurement model of second-order constructs (Becker, Klien and Wetzels, 2012; Hair et al., 2017). The criteria for assessing the first-order constructs of the measurement model such as reliability, convergent validity and discriminant validity also apply to second-order constructs. As Step II in Table 1 reported the results of reflective second-order constructs, suggesting that the second-order constructs met all the minimum requirements of acceptability (Ali, Musawir, and Ali, 2018, Ali, Ali, Badghish, and Baazeem, 2018).

\subsection{Structural model assessment}

This study followed the recommendations in Hair et al. (2017) to evaluate the structural model and testing hypothesis. Before analyzing results from the structural relationship, the collinearity test was conducted by examining the variance inflation factor (VIF) value. This study assessed all possible sets of (predictors) constructs for collinearity. The values of VIF are $<3.3$ or $<5$, suggesting that the structural model has minimal collinearity (Hair et al., 2017).

The predictability in the structural model is analyzed by examining the coefficient of determination or $R^{2}$ value for three endogenous variables. $R^{2}$ may vary depending on the research field. The values of $0.67,0.33$, and 0.19 as measures of $R^{2}$ are suggested to be substantial, moderate, and weak respectively $\left(\right.$ Chin, 2010). The $R^{2}$ (employee engagement) $=0.43, R^{2}$ (employee burnout) $=$ 0.37 , and $R^{2}$ (intention to quit) $=0.52$ suggesting that $R^{2}$ values were moderate and acceptable. The model's predictive relevance in terms of out-of-sample prediction is analyzed by examining the 
$Q^{2}$ values via blindfolding approach. A $Q^{2}$ value $>0$ suggests predictive relevance. The $Q^{2}$ values for all endogenous variables $>0$, suggesting that the model is predictive (Hair et al., 2012).

\subsection{Model fit}

A goodness of fit measure is an index for model validation and obtained by calculating the standardized root-mean square residual (SRMR), (Henseler et al., 2015). Since SRMR is an absolute measure of fit, a value of zero indicates perfect fit, but a value $<0.08$ is generally considered a good fit (Hu \& Bentler, 1998). This study revealed a SRMR $0.07<0.08$, suggesting that the path model fitted with the empirical data (Hair et al., 2017; Henseler et al., 2015).

\subsection{Hypotheses testing}

The sizes and significance levels of the path coefficients represent the derived hypotheses. Following Hair et al. (2017), the significance levels of the path coefficients are obtained using a PLS algorithm, a resampling bootstrapping procedure (with 5000 bootstrap samples and 135 bootstrap cases). The path coefficients, standard errors, significance level, $t$-values as well as the accompanying bootstrap confidence intervals at $95 \%$ are shown in Table 3. An examination of path coefficients and levels of significance suggest that all the direct, and three of the moderating effects are significant. The findings indicate that the direct effect of job insecurity on employee engagement $\left(\beta=0.13^{*}, p<0.05\right)$, employee burnout $\left(\beta=0.50^{* *}, p<0.01\right)$, and intention to quit $(\beta$ $\left.=0.57^{* * *}, p<0.001\right)$ is positive and significant. The moderating results are discussed in next section.

Insert Table 3 here 


\subsection{Conditional moderating effects}

To examine the conditional moderating effects of exogenous variables on endogenous variables at different values of moderating variables, this study employed an inferential test using the PROCESS macro. Using latent variables scores obtained from SmartPLS 3 as an input, this analysis produced estimates and bias-correlated $95 \%$ bootstrap confidence internals for indirect effect with different values of corporate reputation and employee-company identification as moderating constructs.

Table 3 shows that $\mathrm{H} 4 \mathrm{a}$ was not supported as the moderating effect of corporate reputation on the relationship between job insecurity and employee engagement $\left(\beta=-0.02^{\text {n.s. }} ; p>0.05\right)$ is insignificant. There was also no support for $\mathrm{H} 5 \mathrm{a}$ as the employee-company identification has no moderating effect on the relationship between job insecurity and employee engagement $(\beta=0.04$ n.s; $p>0.05)$. In addition, there was no support for $\mathrm{H} 5 \mathrm{c}$ as the moderating effect of employeecompany identification on the relationship between job insecurity and intentions to quit $(\beta=0.03$ n.s. $p>0.05$ ) is insignificant.

The moderating effect of corporate reputation on the relationship between job insecurity and employee burnout $\left(\beta=0.19^{* *} ; p<0.01\right)$ and on the relationship between job insecurity and intention to quit $\left(\beta=0.26^{* *} ; p<0.01\right)$ were significant, in support of $\mathrm{H} 4 \mathrm{~b}$ and $\mathrm{H} 4 \mathrm{c}$ respectively. Also, the moderating effect of employee-company identification on the relationship between job insecurity and employee burnout $\left(\beta=0.15^{*} ; p<0.05\right)$ was significant as shown in Table 4.

Next, this study examined corporate reputation at three levels to determine whether the relationship between job insecurity and employee burnout varies at different levels of corporate reputation (Table 4(A)). These three levels were as follows: the mean $(M=3.54 ; S . D=0.90)$, which was equivalent to the average levels of corporate reputation among the sample; the mean 
minus one standard deviation ( -1 S.D; i.e., 2.54), which was equivalent to low levels of corporate reputation; and the mean plus one standard deviation (+1 S.D; i.e., 4.54), which was equivalent to high levels of corporate reputation. Consistent with H4b, Table 4(A) shows that when corporate reputation was low ( -1 S.D), the conditional effect of job insecurity on employee burnout was positive and significant but weak $(\beta=0.35$, boot $S . E=0.11)$. However, when corporate reputation was high ( +1 S.D), the conditional effect was both positive and significant $(\beta=0.74$, boot S.E $=$ $0.12)$.

These findings supported $\mathrm{H} 4 \mathrm{~b}$ such that the positive effect of job insecurity on employee burnout was moderated by perceived corporate reputation. Fig 2 shows the moderating effect's slope in greater detail. The effect was stronger when corporate reputation was favorable and weaker when corporate reputation was unfavorable. The upper blue line, which represents a low level of corporate reputation, has a flatter slope while the lower green line, which represents a high level of corporate reputation, has a steeper slope. As a rule of thumb and an approximation, the slope of the low level of corporate reputation was the simple effect (i.e., 0.50$)$ minus the interaction effect (0.19), while the slope of high level of corporate reputation was the simple effect (i.e., 0.50) plus the interaction effect $(0.19)$. Hence the simple slope plot supported the previous discussion of the positive interaction term. Higher levels of corporate reputation produced a stronger relationship between job insecurity and employee burnout, while lower levels of corporate reputation led to a weaker relationship between job insecurity and employee burnout. So the moderating effect of corporate reputation on the relationship between job insecurity and employee burnout was generally positive, but increased with increasing levels of corporate reputation. Applying the same procedures, the findings in Table 4(B) were consistent with $\mathrm{H} 4 \mathrm{c}$, which suggested that the positive effect of job insecurity on employee intentions to quit was moderated by perceived corporate 
reputation. Here the effect was also stronger when corporate reputation was favorable and weaker when corporate reputation was unfavorable (Fig. 3). This suggested that the relationship between job insecurity and intentions to quit became stronger with higher levels of corporate reputation. For the low levels of corporate reputation, the slope was much flatter, as shown in Fig 3.

Hence, with low levels of corporate reputation, the relationship between job insecurity and intentions to quit became weaker. Similarly, the findings in Table 4(C) were consistent with H5b, suggesting that the effect of job insecurity on employee burnout was moderated by perceived employee-company identification. The effect was also stronger when employee-company identification was favorable and weaker when employee-company identification was unfavorable (Fig. 4). That is, the relationship between job insecurity and employee burnout became stronger with high level of perceived employee-company identification and for low levels of perceived employee-company identification the slope was much flatter and the relationship between job insecurity and employee burnout becomes weaker.

Insert Table 4 here

\section{Discussion and conclusion}

This study examined the influence of job insecurity on the work-related outcomes of engagement, burnout, and intention to quit in the presence of corporate reputation and employee company identification, amid a government policy of workforce localization. Previous work has highlighted that although there are some apparent organizational benefits to job insecurity, such as employee striving to maintain their post, the negative effects are stronger (Sverke,, Hellgren and Näswall, 2002; Cheng and Chan, 2008; Staufenbiel and König, 2010). To our knowledge job insecurity has not been tested in the context of government localization policies. The results confirm a significant effect of job insecurity in reducing engagement by immigrant employees (H1), such that the 
workforce localization policy risks the productivity of these economically important workers. Policy-induced job insecurity also leads to increased employee burnout $(\mathrm{H} 2)$ and intentions to quit (H3), revealing a stressed and discontent immigrant workforce. Experience is the only control variable that shows a positive and significant effect on employee engagement. This implies that experienced workers tend to be more engaged with the organization, which is also consistent with previous studies (Ageeva et al., 2018). Nevertheless, overall the negative impact of policy induced job insecurity is significant.

Coombs \& Holladay (2001), Dean, (2004), and Jain \& Maheswaran, (2000) have all argued that favorable corporate reputation should reduce any negative effects caused by job insecurity, and indeed this study confirms that corporate reputation has a significant moderating effect between job insecurity (H4a), burnout (H4b) and intentions to quit (H4c), with a stronger effect for higher levels of corporate reputation. Identification with an organization has also been positively associated with a loyal workforce (Ashforth \& Mael, 1989; van Knippenberg \& Sleebos, 2006), and an alignment of employees to the organizational goals (Corley et al., 2006). However, in this study there was insignificant moderation between job insecurity and employee engagement. Even with a good organizational reputation amongst immigrant employees, government localization policies still result in a less engaged workforce. However, when corporate reputation is higher the relationship between job insecurity and burnout is also higher. We theorize that this is because in a highly reputable company, the productivity of employees also tends to be high (for example see Stuebs and Sun, 2010) and therefore the environment is already highly competitive, prior to any impact from localization policies. Those employees who feel insecure with their jobs because of policy may then attempt to work even harder and are thereby more likely to burnout. Previous research shows that favorable corporate reputation protects the organization in a crisis, 
or from adverse external circumstances (Coombs \& Holloday, 2001; Zyglidopoulos, 2005), however, an implication of our findings is that even a strong positive corporate reputation cannot make up for a government policy that is directly aimed at immigrant workers when it comes to their engagement, although it still may protect employees from burnout, and the organization from losing key immigrant workers from resignation.

Employee-company identification has an insignificant moderating role between job insecurity and employee engagement (H5a) and burnout (H5b), but a significant moderating role between job insecurity and intentions to quit (H5c) among immigrant employees. Again, developing strong employee identification can protect a corporation from losing key immigrant staff prematurely in a period of localization, but does not protect against disengagement, and does not reduce burnout. The implications are that although employees may not seek to leave an organization when all other jobs are also vulnerable to localization policy, they do experience stress that can cause them to become disengaged and so potentially less productive.

Overall then, corporate reputation and employee identification does not fully protect the organization from the negative consequences of workforce localization policies. The presence of a powerful new government policy therefore suggests that there are limits to the benefits that previous research has attributed to corporate reputation (see Coombs \& Holladay, 2001; Dean, 2004; Jain \& Maheswaran, 2000). Such an observation may be transferable to other government policy that is capable of 'overriding' the careful work corporations do to develop their corporate reputation and nurture positive employee identification, especially in the six countries of the Arabian Peninsula - Bahrain, Kuwait, Oman, Qatar, the Kingdom of Saudi Arabia, and the United Arab Emirates (Hasan, 2014), but also in other countries where government policy is reacting to political demands to reduce immigrant workforces. 
Although the focus here is immigrant employees as stakeholders, we might also consider the implication of such policy change on how an organization communicates with other stakeholders. The limitations of corporate reputation in maintaining an engaged workforce highlights the need for an effective government lobby, and communication about workforce needs with other external stakeholders to mitigate the impact on immigrant employment on the basis of the potential loss of productivity and related economic impact.

Continued workforce localization may be inevitable in Saudi Arabia (and indeed elsewhere), but the uncertainty and job insecurity that result has serious implications for organizations. Disengagement, burnout and intentions to quit can reduce productivity and harm organizational performance during any transition to a local workforce. Although this may be accepted as a consequence of the policy by government, to ensure a transition that minimizes negative economic effects, corporate lobbying might attempt to influence policy so that it supports corporations and their immigrant employees through localization transitions programs, in particular supporting employee engagement. Where government policy is a response to a electorate, or local population that favors the localization of the workforce, this may also involve communicating the value of immigrant labor more generally in society and here again corporate reputation may prove valuable.

By conveying their concern to government that expatriate employees' knowledge and expertise are important for organizational performance and productivity, organization may also further develop a favorable corporate reputation in immigrant employees. In light of possible economy harm, ideally corporations might ask the government to limit any localization policy in order to retain sufficient number of expatriate workers to maintain organizational performance. Corporations might also convince the government to clearly communicate labor market policies 
regarding the localization of labor markets as any uncertainty in labor market policies towards localization may be harmful even to the expatriate employees who are not likely to lose their job, as they won't know for sure if their job is secure or not. Once the expatriate employees feel that their organization is fulfilling its responsibility to protect their jobs by communicating their importance to the government and other external stakeholders, the employees' perception towards corporate reputation and identification with company should increase, which will in-turn reduce possible negative employees outcomes at work place.

At the organizational level there is also a need for specific and directed intervention to address this situation by reducing ambiguity and communicating an ongoing commitment to important immigrant employees, so ensuring psychological job security such that they work with greater peace of mind and so contribute to achieving organizational goals. Managers can increase employees identification with the company by paying serious attention to improved internal communication with employees (Smidts et al. 2001), providing adequate information to expatriate employees about the governmental and organizational policies related to their job security and the actions taken by the organization to protect their jobs. Indeed where both reputation and identification cannot fully protect immigrant employees, direct support, for example transfers to other offices, visa sponsorship, or nationalization support programs are possible options.

The model developed in this research can be applied to other countries that are undertaking localization, and/or anti-immigration policies in the job market where organizations are known to be reliant on the labor force that is subject to the insecurity that results, for example in the US, in the UK as a result of Brexit, and in Singapore. It would be interesting to also understand how such foreign employees in these developed counties perceive job insecurity under such external policies, 
and if there is any significant change in the work behaviors of respondents with gender, education,

income level, designation, or personality traits

\section{References}

Abbas, M.; Raja, U.; Darr, W.; Bouckenooghe, D. Combined effects of perceived politics and psychological capital on job satisfaction, turnover intentions, and performance. Journal of Management 2014, 40, 1813-1830.

Abdullah, M. I., Ashraf, S., \& Sarfraz, M. (2017). The organizational identification perspective of CSR on creative performance: The moderating role of creative selfefficacy. Sustainability, 9(11), 2125.

Ageeva, E., Melewar, T. C., Foroudi, P., Dennis, C., \& Jin, Z. (2018). Examining the influence of corporate website favorability on corporate image and corporate reputation: findings from fsQCA. Journal of Business Research.

Al-Dosary AS, Rahman SM. Saudization (localization) - a critical review. Human Resource Development International 2005;8(4):495-502.

Al-Asfour, A. and Khan, S.A., 2014. Workforce localization in the Kingdom of Saudi Arabia: Issues and challenges. Human Resource Development International, 17(2), pp.243-253.

Alexander, H. Donald Trump backs plan to cut immigration by half in 10 years. The Telegraph. 2017. Available at http://www.telegraph.co.uk/news/2017/08/02/donald-trump-announcessupport-plan-reduce-legal-immigration/

Ali, I. Influence of corporate social responsibility on development of corporate reputation and customer purchase intention. Romanian Review of Social Sciences, 2011, 1, 19-27.

Ali, I., \& Zia, M. (2011). Corporate reputation influences consumer satisfaction and loyalty: evidence from cellular industry of Pakistan. Paper presented at International Conference on Challenges for Knowledge Society, held on 15-16 April 2011 at Bucharest, Romania.

Ali, I., Ali, M., Badghish, S., \& Baazeem, T. A. S. Examining the Role of Childhood Experiences in Developing Altruistic and Knowledge Sharing Behaviors among Children in Their Later Life: A Partial Least Squares (PLS) Path Modeling Approach. Sustainability, 2018, 10(2), 292.

Ali, I., Musawir, A. U., \& Ali, M. (2018). Impact of knowledge sharing and absorptive capacity on project performance: the moderating role of social processes. Journal of Knowledge Management, 22(2), 453-477.

Ali, R., Lynch, R., Melewar, T. C., \& Jin, Z. (2015). The moderating influences on the relationship of corporate reputation with its antecedents and consequences: A meta-analytic review. Journal of Business Research, 68(5), 1105-1117.

Aljead HM. Attraction and Retention policies of Saudi Educational Institutions for Expatriates. College of Business, Effat University Jeddah, Saudi Arabia; 2014.

Alniacik U, Cigerim E, Akcin K, Bayram O. Independent and joint effects of perceived corporate reputation, affective commitment and job satisfaction on satisfaction on turnover intentions. Procedia Social and Behavioral Sciences 2011, 24: 1177-1189

Arab News. Saudization directly affects economic growth: Labor minister. Available at http://www.arabnews.com/node/1073226/saudi-arabia; 2017. 
Ashforth BE, Mael F. Social identity theory and the organization. Academy of Management Review 1989;14(1):20-39.

Ashford S, Lee C, Bobko P. Content, Causes and Consequences of Job Insecurity: A Theory-Based Measure and Substantive Test. Academy of Management Journal 1989;32(4):803-829.

Ashforth B, Harrison S, Corley K. Identification in Organizations: An Examination of Four Fundamental Questions. Journal of Management 2008;34(3):325-374.

Aybas, M., Elmas, S., and Dundar, G. Job Insecurity and Burnout: The Moderating Role of Employability, European Journal of Business and Management, 2015; 7,9;195-202.

BBC (2017). Conservative manifesto summary: Key points at-a-glance. BBC. Available at http://www.bbc.co.uk/news/election-2017-39960311

Becker, J. M., Klein, K., \& Wetzels, M. (2012). Hierarchical latent variable models in PLS-SEM: guidelines for using reflective-formative type models. Long Range Planning, 45(5-6), 359394.

Beheshtifar, M.B., and Allahyary, M.H., Study the Relationship among Organizational Reputation with Organizational commitment and Employees' Turnover Intention, International Research Journal of Applied and Basic Sciences, 2013, 6 (10): 1467-1478.

Berntson, Erik, Katharina Näswall, and Magnus Sverke. "The moderating role of employability in the association between job insecurity and exit, voice, loyalty and neglect." Economic and Industrial Democracy 31, no. 2 (2010): 215-230.

Bouckenooghe, D., Raja, U., Butt, A. N., Abbas, M., \& Bilgrami, S. (2017). Unpacking the curvilinear relationship between negative affectivity, performance, and turnover intentions: The moderating effect of time-related work stress. Journal of Management \& Organization, 23(3), 373-391.

Cheng, G.H.L. and Chan, D.K.S., 2008. Who suffers more from job insecurity? A meta analytic review. Applied Psychology, 57(2), pp.272-303.

Chin WW. The partial least squares approach for structural equation modeling, in Marcoulides, G.A. (Ed.), Modern Methods for Business Research, Mahwah, NJ:Lawrence Erlbaum Associates; 1998.

Chirumbolo, A., and Areni, A. 2005. The influence of job insecurity on job performance and absenteeism: the moderating effect of work attitudes, South African Journal of Industrial Psychology, 31(4): 65-71

Choi S, Cheong KJ, Feinberg RA. Moderating effects of supervisor support, monetary rewards, and career paths on the relationship between job burnout and turnover intentions in the context of call centers. Managing Service Quality: An International Journal 2012;22(5):492516.

Cobb S, Kasl SV. Termination: The Consequences of Job Loss. Cincinnati: US Department of Health Education and Welfare; 1977.

Colarelli SM. Methods of communication and mediating processes in realistic job previews. Journal of Applied Psychology 1984;69(4):633-42.

Coombs T, Holladay S. An Extended Examination of the Crisis Situations: A Fusion of the Relational Management and Symbolic Approaches. Journal of Public Relations Research 2001;13(4):321-340.

Corley KG, Harquail CV, Pratt MG, Glynn MA, Fiol CM, Hatch MJ. Guiding organizational identity through aged adolescence. Journal of Management Inquiry 2006;15(2):85-99.

Cuyper ND, Bernhard OC, Berntson E, Witte HD, Alarco B. Employability and employees' wellbeing: Mediation by job insecurity. Applied Psychology 2008;57(3):488-509. 
DeConinck, J. B. (2011). The effects of ethical climate on organizational identification, supervisory trust, and turnover among salespeople. Journal of Business Research, 64(6), 617-624.

Dekker SW, Schaufeli WB. The effects of job insecurity on psychological health and withdrawal: A longitudinal study. Australian psychologist, (1995):30(1), 57-63.

Deloitte report (2016). Reputation matters: developing reputational resilience ahead of crises. Retrieved

from https://www2.deloitte.com/content/dam/Deloitte/uk/Documents/risk/deloitte-uk-reputationmatters-june-2016.pdf

De Witte, H. (2000) 'Arbeidsethos en Jobonzekerheid: Meting en Gevolgen voor Welzijn, Tevredenheid en Inzet op het Werk', pp. 325-50 in R. Bouwen, K. De Witte, H. De Witte and T. Taillieu (eds)Van Groep naar Gemeenschap. LiberAmicorum Prof. Dr. Leo Lagrou.Leuven: arant.

De Witte, H. 2005. Job insecurity: review of the international literature on definitions, prevalence, antecedents and consequences, South African Journal of Industrial Psychology, 31(4): 1-6.

Dean D. Consumer reaction to negative publicity: Effects of corporate reputation, response, and responsibility for a crisis event. Journal of Business Communication 2004; 41(2):192-211.

El-Kassar, AN., Yunis, M. \& El-Khalil, R., (2017): The Mediating Effects of Employee-Company Identification on the Relationship between Ethics, Corporate Social Responsibility, and Organizational Citizenship Behavior, Journal of Promotion Management, DOI: 10.1080/10496491.2017.1294872

Feldman PM, Vasquez-Parraga AZ. Consumer social responses to CSR initiatives versus corporate abilities. Journal of Consumer Marketing 2013;30(2):100-111.

Festinger L. A Theory of Cognitive Dissonance, Stanford: Stanford University Press; 1957.

Foroudi, P., Jin, Z., Gupta, S., Melewar, T. C., \& Foroudi, M. M. (2016). Influence of innovation capability and customer experience on reputation and loyalty. Journal of Business Research, 69(11), 4882-4889.

Fornell C, Larcker DF. Structural equation models with unobservable variables and measurement error: Algebra and statistics. Journal of marketing research 1981:382-388.

Furåker B, Berglund T. Job Insecurity and Organizational Commitment. International Journal of Organizations/Revista Internacional de Organizaciones 2014;13.

Gaultier-Gaillard S, Louisot, J. Risks to Reputation: A Global Approach. The Geneva Papers 2006;31(3):425-445.

Gefen D, Straub D. A practical guide to factorial validity using PLS-Graph: Tutorial and annotated example. Communications of the Association for Information systems 2005;16(1):5.

Gosh, S.K. "The direct and interactive effects of job insecurity and job embeddedness on unethical pro-organizational behavior: An empirical examination", Personnel Review, 2017; 46 ,6, 1182-1198,

Greasley, K., Bryman, A., Price, A., Soetanto, R., \& King, N. (2005). Employee perceptions of empowerment. Employee Relations, 27, 354-368.

Greenhalgh, L., \& Rosenblatt, Z. 1984. Job insecurity: Toward conceptual clarity. Academy of Management Review, 9: 438-448.

Guarana, C.L.O (2010). The Moderator effect of Organizational Identification on the relationship between Work Context and Workforce Engagement/Burnout. Master thesis Graduate School of The Ohio State University, USA.

Hair JF, Sarstedt M, Ringle CM, Mena JA. An assessment of the use of partial least squares 
structural equation modeling in marketing research. Journal of the Academy of Marketing Science 2012;40(3):414-433.

Hair JF, Hult GTM, Ringle CM, Sarstedt M. A Primer on Partial Least Squares Structural Equation Modeling (PLS-SEM). $2^{\text {nd }}$ edition, Sage, CA:Thousand Oaks;2017.

Hallier J, Lyon P. Job Insecurity and Employee Commitment: Managers' Reactions to the Threat and Outcomes of Redundancy Selection. British Journal of Management 1996;7(1):107-123.

Hartley J, Jacobson D, Klandermans B, van Vuuren T. Job Insecurity: Coping with Jobs at Risk. London: Sage; 1991.

Hasan, S. (2014). Workforce localization in the GCC countries: policies, practices, and the laborexporting countries' responses. Philippine Political Science Journal, 36(2),

Hayes AF. Introduction to mediation, moderation, and conditional process analysis: A regressionbased approach. Guilford Press; 2013.

Helm S. Employees' awareness of their impact on corporate reputation, Journal of Business Research 2011, 64, 657-663.

Helm S, Tolsdrof J. How does corporate reputation affect customer loyalty in a reputation crises? Journal of Contingencies and Crisis Management 2013;21(3):144-152.

Henseler, J.; Dijkstra, T.K.; Sarstedt, M.; Ringle, C.M.; Diamantopoulos, A.; Straub, D.W.; David J. Ketchen, J.; Hair, J.F.; Hult, G.T.M.; Calantone, R.J. Common beliefs and reality about pls:Comments on rönkkö and evermann (2013). Organizational Research Methods 2014, 17, 182-209.

Henseler J, Ringle CM, Sarstedt M. A new criterion for assessing discriminant validity in variancebased structural equation modeling. Academy of Marketing Science Journal 2015;43(1):115.

Highhouse S, Broadfoot A, Yugo JE, Devendorf SA. Examining corporate reputation judgments with generalizability theory. Journal of Applied Psychology. 2009;94(3):782-9.

$\mathrm{Hu}$ LT, Bentler PM. Cutoff criteria for fit indexes in covariance structure analysis: Conventional criteria versus new alternatives. Structural equation modeling: a multidisciplinary journal 1999;6(1):1-55.

Ismail, Hassan. "Job insecurity, Burnout and Intention to Quit." International Journal of Academic Research in Business and Social Sciences 5, no. 4 (2015): 310-324.

Jain SP, Maheswaran D. Motivated Reasoning: A Depth-of- Processing Perspective. Journal of Consumer Research 2000;26(4):358-371.

Jiménez, P., Milfelner, B., Šarotar Žižek, S., \& Dunk1, A. (2017). Moderating Effects between Job Insecurity and Intention to Quit in Samples of Slovene and Austrian Workers. Naše gospodarstvo/Our Economy, 63(1), 27-37.

Khan, K., Abbas, M., Gul, A., \& Raja, U. (2015). Organizational justice and job outcomes: Moderating role of Islamic work ethic. Journal of Business Ethics, 126(2), 235-246.

Kock N (2014). One-tailed or two-tailed P values in PLS-SEM? Laredo, TX: Script-Warp Systems.

Kock, N. (2015). Common method bias in PLS-SEM: A full collinearity assessment approach. International Journal of e-Collaboration (IJeC), 11(4), 1-10.

László, K. D., Pikhart, H., Kopp, M. S., Bobak, M., Pajak, A., Malyutina, S., \& Marmot, M. (2010). Job insecurity and health: a study of 16 European countries. Social science \& medicine, 70(6), 867-874.

Qasim, S., Siam, MRA. and Sarkawi, MNM. The effect of CSR on brand loyalty: the moderating role of corporate reputation and mediates the brand image. Asian Journal of Empirical Research, 2017, vol. 7, issue 10, 251-259 
Lazarus RS, Folkman S. Stress, Appraisal and Coping. New York: Springer; 1984

Lindell, M. K. and D. J. Whitney (2001). Accounting for common method variance in cross-sectional research designs. Journal of Applied Psychology 86(1): 114-121.

Lowry, P. B., \& Gaskin, J. (2014). Partial least squares (PLS) structural equation modeling (SEM) for building and testing behavioral causal theory: When to choose it and how to use it. IEEE transactions on professional communication, 57(2), 123-146.

Mael F, Ashforth BE. Alumni and their alma mater: A partial test of the reformulated model of organizational identification. Journal of organizational Behavior 1992;13(2):103-123.

Manzano-García, G., and Ayala, J.C. (2017). Relationship between psychological capital and psychological well-being of direct support staff of specialist autism services. The mediator role of burnout. Frontiers in Psychology, 8: 2277.

Maslach C, Jackson SE. The measurement of experienced burnout. Journal of Occupational Behavior 1981;2(2):99-113.

Meyer, J. P., Becker, T. E., \& Vanderberghe, C. (2004). Employee Commitment and Motivation: A Conceptual Analysis and Integrative Model. Journal of Applied Psychology, 89, 991-1007.

McLean, T. 2006. Heavy workloads, job insecurities lead to more sick days, Australian Associated Press: General News Wire

Meyer JP, Parfyonova NM. Normative commitment in the workplace: A theoretical analysis and re-conceptualization. Human resource management review 2010;20(4):283-294.

Musteen M, Datta DK, Kemmerer B. Corporate reputation: Do board characteristics matter?. British Journal of Management 2010;21(2):498-510.

Naseer, S., Raja, U., Syed, F., Donia, M. B., \& Darr, W. (2016). Perils of being close to a bad leader in a bad environment: Exploring the combined effects of despotic leadership, leader member exchange, and perceived organizational politics on behaviors. The Leadership Quarterly, 27(1), 14-33.

Niesen, W., Hootegem, A.V. Elst, TV. Battistelli A., and Witte, HD Job Insecurity and Innovative Work Behaviour: A Psychological Contract Perspective. Psychologica Belgica, 2018; 57(4), pp. 174-189,

Nunnally J. Psychometric methods. 1978; 464-465.

O'Rourke, Kevin (2016) The lesson from Brexit is that too much market and too little state invites a backlash. LSE European Politics and Policy (EUROPP) Blog (24 Aug 2016). Blog Entry.

Petter, S. (2018). Haters Gonna Hate: PLS and Information Systems Research. ACM SIGMIS Database: the DATABASE for Advances in Information Systems, 49(1), 10-13.

Pires, V., Trez, G. (2018) "Corporate reputation: A discussion on construct definition and measurement and its relation to performance", Revista de Gestão, 25: 1, 47-64,

Payan, T. (2016). Immigration and the United States: A Path to Resolution. Baker Institute for Public Policy. Available at https://scholarship.rice.edu/bitstream/handle/1911/93920/BIBrief-2016-Rec_Payan.pdf?sequence $=1$

Piccoli, B. and De Witte, H. "Job insecurity and emotional exhaustion: testing psychological contract breach versus distributive injustice as indicators of lack of reciprocity", Work and Stress, (2015), 29,3, 246-263.

Piccoli, B., Callea, A., Urbini, F. Chirumbolo, A., Ingusci, E., and De Witte, HD. Job insecurity and performance: the mediating role of organizational identification", Personnel Review, 2017; 46, 8, 1508-1522,

Podsakoff, P. M., \& Organ, D. W. (1986). Self-reports in organizational research: Problems and prospects. Journal of Management, 12(4), 531-544. 
Presti, A.L., and Nonnis, M. Moderated Effects Of Job Insecurity On Work Engagement And Distress. TPM 2012; 19, 2, 97-113.

Ramady, M. A. 2005. The Saudi Arabian Economy: Policies, Achievements and Challenges. New York: Springer Science Business Media.

Ramady, M., 2013. Gulf unemployment and government policies: Prospects for the Saudi labour quota or Nitaqat system. International Journal of Economics and Business Research, 5(4), pp.476-498.

Rhee M, Haunschild PR. The Liability of Good Reputation: A Study of Product Recalls in the U.S. Automobile Industry. Organization Science 2006;17(1):101-117.

Richter, N.F.; Cepeda, G.; Roldán, J.L.; Ringle, C.M. European management research using partial least squares structural equation modeling (pls-sem). European Management Journal 2015, 33, $1-3$.

Rigdon, E.E. Choosing pls path modeling as analytical method in european management research: A realist perspective. European Management Journal 2016, 34, 598-605.

Riketta, M. (2005). Organizational Identification: A meta-Analysis. Journal of Vocational Behavior, 66, 358-384.

Ringle C. M, Wende S, Becker J. M. SmartPLS 3. (2015). SmartPLS. Available at http://www.smartpls.com.

Roldán, J.L.; Sánchez-Franco, M.J. Variance-based structural equation modeling: Guidelines for using partial least squares in information systems research. In M. Mora (Ed.), R.m., innovations and philosophies in software systems engineering and information systems, Ed. PA: IGI Global: Hershey, 2012; pp 193-221.

Rönkkö, M.; Evermann, J. A critical examination of common beliefs about partial least squares path modeling. Organizational Research Methods 2013, 16, 425-448.

Rönkkö, M.; McIntosh, C.N.; Antonakis, J. On the adoption of partial least squares in psychological research: Caveat emptor. Personality and Individual Differences 2015, 87, 7684.

Rönkkö, M.; McIntosh, C.N.; Antonakis, J.; Edwards, J.R. Partial least squares path modeling: Time for some serious second thoughts. Journal of Operations Management 2016, 47-48, 927.

Roskies E, Louis-Guerin C. Job Insecurity in Managers: Antecedents and Consequences. Journal of Organizational Behavior 1990;11(5):345-359.

Ruhs, M. and Anderson, B. eds., 2010. Who needs migrant workers?: labour shortages, immigration, and public policy. Oxford University Press.

Saks AM. Antecedents and consequences of employee engagement. Journal of Managerial Psychology 2006;21(7):600-619.

Schaufeli WB, Bakker AB, Salanova M. The measurement of work engagement with a short questionnaire: A cross-national study. Educational and psychological measurement 2006;66(4):701-716.

Saudi Gazetta. New Saudization Program Unveiled. Available at http://saudigazette.com.sa/saudiarabia/new-saudization-program-unveiled/; 2016.

Saudi Gazetta. Saudi reforms on track to achieve Vision 2030. Retrieved on May 02, 2017 from http://saudigazette.com.sa/business/saudi-reforms-track-achieve-vision-2030/; 2017.

Sarstedt, M.; Hair, J.F.; Ringle, C.M.; Thiele, K.O.; Gudergan, S.P. Estimation issues with pls and cbsem: Where the bias lies! Journal of Business Research 2016, 69, 3998-4010. 
Sarstedt, M.; Ringle, C.M.; Hair, J.F. Partial least squares structural equation modeling. In Handbook of market research, Homburg, C.; Klarmann, M.; Vomberg, A., Eds. Springer International Publishing: Cham, 2017; pp 1-40.

Shirin, A., \& Kleyn, N. An Evaluation of the Effects of Corporate Reputation on Employee Engagement: The Case of a Major Bank in South Africa, International Studies of Management \& Organization, (2017) 47:3, 276-292.

Sridhar, M. \& Mehta, A. The Moderating and Mediating Role of Corporate Reputation in the Link Between Service Innovation and Cross-Buying Intention, Corporate Reputation Review (2018). https://doi.org/10.1057/s41299-018-0044-9.

Smidts, A., Pruyn A.T.H., and Riel, C.B.M. 2001. The impact of employee communication and perceived external prestige on organizational identification. Academy of Management, 49(5), 1051-1062.

Stander, M.W., \& Rothmann, S. (2010). Psychological empowerment, job insecurity and employee engagement. SA Journal of Industrial Psychology, 36(1), Art. \#849, 8 pages. DOI: 10.4102/sajip.v36i1.849

Staufenbiel, T. and König, C.J., 2010. A model for the effects of job insecurity on performance, turnover intention, and absenteeism. Journal of Occupational and Organizational Psychology, 83(1), pp.101-117.

Stuebs, M., \& Sun, L. (2010). Business reputation and labor efficiency, productivity, and cost. Journal of Business Ethics, 96(2), 265-283.

Su, L. Swanson, SR. Chinchanachokchai, S. Hsu, MK. and Chen X. Reputation and intentions: The role of satisfaction, identification, and commitment. Journal of Business Research 69 (2016) 3261-3269

Sverke, M., Hellgren, J. and Näswall, K., 2002. No security: a meta-analysis and review of job insecurity and its consequences. Journal of occupational health psychology, 7(3), p.242.

Tan, E. (2017). Quality immigration will remain Singapore's lifeblood. Today. Available at http://www.todayonline.com/singapore/quality-immigration-will-remain-singaporeslifeblood

Tajfel H. Social categorization, social identity and social comparison. In H Tajfel (Ed.), Differentiation between social groups: Studies in the social psychology of intergroup relations: 61-76. London: Academic Press; 1978.

Tilakdharee, N., Ramidial, S., and Parumasur, SB. The relationship between job insecurity and burnout, South African Journal of Economics and Management Sciences, 2010; 13, 3, 254271.

Tischer, S., \& Hildebrandt, L. (2014). Linking corporate reputation and shareholder value using the publication of reputation rankings. Journal of Business Research, 67(5), 1007-1017.

Tucker L, Melewar T. Corporate Reputation and Crisis Management: The Threat and Manageability of Anti-Corporatism. Corporate Reputation Review 2005;7(4):377-387.

Van Knippenberg D, Sleebos E. Organizational identification versus organizational commitment: self-definition, self-exchange and job attitudes. Journal of Organizational Behavior 2006;27(5):571-584.

Vander Elst T, De Witte H, De Cuyper N. The Job Insecurity Scale: A psychometric evaluation across five European countries. European Journal of Work and Organizational Psychology 2014; 23(3):364-380. 
Wang, D. H. M., Yu, T. H. K., \& Chiang, C. H. (2016). Exploring the value relevance of corporate reputation: A fuzzy-set qualitative comparative analysis. Journal of Business Research, 69(4), 1329-1332.

Wang, W., Fu, Y., Qiu, H., Moore, J.H. and Wang Z., Corporate Social Responsibility and Employee Outcomes: A Moderated Mediation Model of Organizational Identification and Moral Identity, Frontiers in Psychology. 2017; 8: 1906.

Wagner, T., Lutz, R. J., \& Weitz, B. A. (2009). Corporate hypocrisy: overcoming the threat of inconsistent corporate social responsibility perceptions. Journal of Marketing, 73, 77-91.

Watson, T. (2007) "Reputation and ethical behavior in a crisis: predicting survival", Journal of Communication Management, 11;4, 371-384,

Zafar, M. \& Ali, I. (2016). The Influence of Corporate Social Responsibility on Employee Commitment: The Mediating Role of Employee Company Identification, Asian Social Science; 12,$12 ; 2662-280$.

Zyglidopoulos SC. The impact of downsizing on corporate reputation. British Journal of Management 2005;16(3):253-259. 